\title{
PENGARUH DOSIS VERMIKOMPOS TERHADAP PERTUMBUHAN TANAMAN PAKCOY (Brassica rapa L.) dan PERUBAHAN BEBERAPA SIFAT KIMIA TANAH ULTISOL TAMAN BOGO
}

\author{
I Gusti Putu Setiawan, Ainin Niswati, Kus Hendarto \& Sri Yusnaini \\ Jurusan Agroteknologi Fakultas Pertanian Universitas Lampung, \\ Jl. Sumantri Brojonegoro No.1 Bandar Lampung 35145
}

\begin{abstract}
ABSTRAK
Penggunaan pupuk akhir-akhir ini semakin berkembang, bahkan cenderung mutlak diperlukan. Pada tanah pertanian sering digunakan pupuk buatan atau kimia. Penggunaaan pupuk kimia secara terus-menerus dalam jangka waktu yang lama dapat menimbulkan kerusakan lingkungan dan menyebabkan produktivitas tanah menurun. Untuk mengurangi dampak kerusakan lingkungan akibat penggunaan pupuk kimia, petani dapat menggunakan pupuk organik yang memiliki potensi tinggi untuk meningkatkan kesuburan tanah, salah satu pupuk organik yang dapat digunakan tersebut adalah vermikompos. Pemupukan ini dimaksudkan untuk menambahkan unsur hara tanah yang semakin lama semakin berkurang karena terserap oleh tanaman untuk memenuhi kebutuhan hidupnya. Pakcoy (Brassica rapa L.) adalah jenis tanaman sayur-sayuran yang termasuk keluarga Brassicaceae. Media tanam adalah tanah yang cocok untuk ditanami pakcoy adalah tanah gembur, banyak mengandung humus, subur, serta pembuangan airnya baik derajat kemasaman $(\mathrm{pH})$ tanah yang optimum untuk pertumbuhannya adalah antara pH 5 sampai pH 7. Penelitian dilaksanakan dari bulan Mei sampai Juli 2013. Penelitian ini dilakukan dengan menggunakan Rancangan Acak Kelompok (RAK) dengan 6 ulangan, secara keseluruhan penelitian ini terdiri dari 24 satuan percobaan . Perlakuan yang digunakan adalah Kontrol, Tanah dengan $10 \%$ (0,5 kg vermikompos), Tanah dengan $20 \%$ (1 kg vermikompos), Tanah dengan $30 \%$ (1,5 kg vermikompos). Data yang diperoleh dirata-ratakan, kemudian diuji homogenitasnya dengan uji Bartlet dan aditivitasnya dengan uji Tukey. Selanjutnya data dianalisis dengan analisis ragam pada taraf $5 \%$. Untuk mengetahui beda nilai tengah dilakukan uji BNT pada taraf 5\%, serta untuk melihat hubungan antara pertumbuhan tanaman dengan $\mathrm{pH}$, C-organik, dan N-total dilakukan uji korelasi pada taraf 5\%. Hasil penelitian menunjukkan bahwa aplikasi vermikompos $20 \%$ menghasilkan bobot tanaman pakcoy yang paling tinggi dibandingkan dengan perlakuan lainnya. Aplikasi vermikompos mempengaruhi sifat kimia tanah ,yaitu melalui proses dekomposisi bahan organik oleh mikroba tanah. Hasil analisis kimia tanah menunjukan hasil analisis tanah setelah pertanaman dengan $\mathrm{pH}$ yang mengalami kenaikan disetiap perlakuan yaitu dari pH awal tanah 4,69 menjadi berkisar antara 5,64 sampai6,98, untuk N-total tanah 1,70 menjadi berkisar 0,07 sampai 0,63, dan untuk C-organik berpenurunan dari 6,6 menjadi 0,6 sampai 3,50.
\end{abstract}

Kata kunci: pakcoy, sifat kimia tanah, vermikompos

\section{PENDAHULUAN}

Seiring dengan bertambahnya penduduk dan meningkatnya kesejahteraan penduduk, kebutuhan akan pangan dan sayuran segar juga terus meningkat. Untuk meningkatkan produksi pangan diperlukan tanah yang subur. Pemupukan merupakan salah satu komponen penting dalam usaha meningkatkan kesuburan tanah. Petani biasanya melakukan pemupukan dangan menggunakan pupuk kimia seperti Urea, SP36, $\mathrm{KCl}$ dan sebagainya. Di samping menggunakan pupuk kimia, petani juga sering menggunakan pupuk organik yang memiliki potensi tinggi untuk meningkatkan kesuburan tanah, salah satu pupuk organik yang dapat digunakan tersebut adalah vermikompos. Pemupukan ini dimaksudkan untuk menambahkan unsur hara tanah yang semakin lama semakin berkurang karena terserap oleh tanaman untuk memenuhi kebutuhan hidupnya
(Sutedjo dkk., 1991). Jika kekurangan ini berlangsung secara terus menerus, akan mengakibatkan terjadinya degradasi kesuburan tanah, sehingga pertumbuhan dan produktivitas tanaman akan terganggu (Syekhfani, 2003).

Penggunaan pupuk akhir-akhir ini semakin berkembang, bahkan cenderung mutlak diperlukan. Pada tanah pertanian sering digunakan pupuk buatan atau kimia. Penggunaaan pupuk kimia secara terus-menerus dalam jangka waktu yang lama dapat menimbulkan kerusakan lingkungan dan menyebabkan produktivitas tanah menurun. Penggunaan vermikompos di maksudkan untuk mengurangi pupuk kimia yang cendrung mahal, hal ini dapat merepotkan petani, karena kebanyakan petani memiliki modal yang sedikit. Untuk menghemat biaya dan mencegah kerusakan lahan lebih lanjut, diperlukan penggunaan pupuk organik sebagai alternatif pilihan atau substitusi sebagian dari pupuk kimia. 
Vermikompos merupakan pupuk organik dari perombakan bahan-bahan organik dengan bantuan mikroorganisme dan cacing tanah. Dalam proses dekomposisi bahan kompos oleh cacing tanah, hasil dekomposisi tersebut mengandung berbagai unsur hara dan kaya akan zat pengatur tumbuh yang mendukung pertumbuhan tanaman. Menurut Zahid (1994) vermikompos mengandung zat pengatur tumbuh seperti giberellin, sitokinin dan auxin, serta unsur hara $\mathrm{N}, \mathrm{P}, \mathrm{K}$, $\mathrm{Mg}$ dan $\mathrm{Ca}$ dan Azotobacter sp yang merupakan bakteri penambat $\mathrm{N}$ nonsimbiotik yang akan membantu memperkaya unsur $\mathrm{N}$ yang dibutuhkan oleh tanaman. Vermikompos juga mengandung berbagai unsur hara mikro yang dibutuhkan tanaman seperti $\mathrm{Fe}, \mathrm{Mn}, \mathrm{Cu}, \mathrm{Zn}$, Bo dan Mo (Mashur, 2001).

Akhir-akhir ini tanah subur untuk tanaman sayuran semakin berkurang. Oleh karena itu produksi tanaman sayuran akan berekspansi ke tanah yang relatif kurang subur seperti tanah Ultisol. Permasalahannya adalah apakah vermikompos dapat meningkatkan kesuburan tanah ultisol dan berapa dosis yang yang baik bagi tanaman sayuran, khususnya pakcoy.

\section{BAHAN DAN METODE}

Penelitian ini dilaksanakan dari bulan Mei sampai Juli 2013. Penyemaian benih, penanaman pakcoy dan aplikasi vermikompos dilakukan di kebun percobaan laboratoriun lapangan terpadu Fakultas Pertanian Universitas Lampung.

Peralatan yang digunakan antara lain Polibag, bak pasir untuk penyemaian, hand sprayer, alat tulis, ayakan $5 \mathrm{~mm}$, alat tulis, penggaris, timbangan, ember, alat hitung, oven.Bahan-bahan yang digunakan dalam penelitian ini antara lain Tanah Ultisol yang diambil dari kebun percobaan Taman Bogo, benih pakcoy, vermikompos, air, label dan polibag.

Penelitian ini dilakukan dengan menggunakan Rancangan Acak Kelompok (RAK) dengan 6 ulangan, secara keseluruhan penelitian ini terdiri dari 24 satuan percobaan. Adapun perlakuan yang digunakan adalah Kontrol, Tanah $+10 \%(0,5 \mathrm{~kg}$ vermikompos/media pertanaman), Tanah $+20 \%$ (1 kg vermikompos/media pertanaman), Tanah $+30 \%$ (1,5 kg vermikompos/media pertanaman).

Data yang diperoleh dirata-ratakan, kemudian diuji homogenitasnya dengan uji Bartlet dan aditivitasnya dengan uji Tukey. Selanjutnya data dianalisis dengan analisis ragam pada taraf 5\%. Untuk mengetahui beda nilai tengah dilakukan uji BNT pada taraf $5 \%$, serta untuk melihat hubungan antara pertumbuhan tanaman dengan $\mathrm{pH}, \mathrm{C}$-organik, dan $\mathrm{N}$-total dilakukan uji korelasi pada taraf $5 \%$.

Pengamatan dilakukan terhadap tinggi tanaman, jumlah daun, bobot basah dan kering berangkasan, $\mathrm{pH}$, $\mathrm{C}$-organik dan $\mathrm{N}$-total tanah awal, serta $\mathrm{pH}, \mathrm{C}$-organik dan N-total tanah setelah panen.

\section{HASIL DAN PEMBAHASAN}

Bobot Basah. Hasil uji BNT pada taraf 5\% (Tabel 1), menunjukkan bahwa pada pemberian dosis vermikompos terhadap bobot basah tanaman pakcoy pada tanah Ultisol Taman Bogo terendah pada kontrol (tanpa diberi vermikompos), diikuti dengan pemberian dosis $10 \%$ (0,5 $\mathrm{kg}$ vermikompos/ media tanam) dan pemberian dosis $30 \%$ (1,5 kgvermikompos/media tanam) dan tertinggi pada pemberian dosis $20 \%$ (1 kgvermikompos/ media tanam).

Tabel 1. Pengaruh pemberian dosis vermikompos terhadap bobot basah tanaman pakcoy pada tanah Ultisol Taman Bogo

\begin{tabular}{cc}
\hline Perlakuan & Bobot basah $\left(\mathrm{g} \mathrm{tan}^{-1}\right)$ \\
\hline Kontrol & $7,08 \mathrm{a}$ \\
Vermikompos $(10 \%)$ & $35,00 \mathrm{~b}$ \\
Vermikompos $(20 \%)$ & $56,84 \mathrm{c}$ \\
Vermikompos (30\%) & $43,88 \mathrm{bc}$ \\
\hline BNT 5\% & 15,89 \\
\hline Keterangan: Angka yang diikuti oleh huruf yang sama \\
menunjukkan tidak berbeda nyata dengan \\
uji BNT pada taraf nyata BNT 5\%
\end{tabular}

Bobot Kering. Hasil uji BNT pada taraf 5\% (Tabel 2), menunjukkan bahwa pada pemberian dosis vermikompos terhadap bobot basah tanaman pakcoy pada tanah Ultisol Taman Bogo terendah pada kontrol (tanpa diberi vermikompos), diikuti dengan pemberian dosis $10 \%$ (0,5 kg vermikompos/ media tanam) dan pada pemberian dosis $20 \%$ ( $1 \mathrm{~kg}$ vermikompos/media tanam) dan tertinggi pada pemberian dosis $30 \%(1,5 \mathrm{~kg}$ vermikompos/ media tanam).

Tinggi Tanaman. Hasil uji BNT pada taraf 5\% (Tabel 3 ), menunjukkan bahwa pada pemberian dosis vermikompos terhadap bobot basah tanaman pakcoy pada tanah Ultisol Taman Bogo terendah pada kontrol (tanpa diberi vermikompos), diikutin dengan pemberian dosis $30 \%$ (1,5 kg vermikompos/ media tanam) dan pemberian dosis $20 \%$ (1 kg vermikompos/ media tanam) 
Tabel 2. Pengaruh pemberian dosis vermikompos terhadap bobot kering tanaman pakcoy pada tanah Ultisol Taman Bogo

\begin{tabular}{cc}
\hline Perlakuan & Bobot kering $\left(\mathrm{g} \mathrm{tan}^{-1}\right)$ \\
\hline Kontrol & $2,20 \mathrm{a}$ \\
Vermikompos $(10 \%)$ & $4,37 \mathrm{~b}$ \\
Vermikompos $(20 \%)$ & $6,77 \mathrm{c}$ \\
Vermikompos $(30 \%)$ & $7,24 \mathrm{c}$ \\
\hline BNT 5\% & 1,92
\end{tabular}

Keterangan: Angka yang diikuti oleh huruf yang sama menunjukkan tidak berbeda nyata dengan uji BNT pada taraf nyata BNT 5\%

dan tertinggi pada pemberian dosis $10 \%(0,5 \mathrm{~kg}$ vermikompos/ media tanam).

Jumlah Daun. Hasil uji BNT pada taraf 5\% (Tabel 4), menunjukkan bahwa pada pemberian dosis vermikompos terhadap bobot basah tanaman pakcoy pada tanah Ultisol Taman Bogo terendah pada kontrol (tanpa diberi vermikompos), diikuti dengan pemberian dosis 30\% (1,5 kg vermikompos/ media tanam), pada pemberian dosis $10 \%(0,5 \mathrm{~kg}$ vermikompos/ media tanam) dan pada pemberian dosis 20\% (1 kg vermikompos/ media tanam)

Hasil analisis kimia tanah menunjukan hasil analisis tanah setelah pertanaman dengan $\mathrm{pH}$ yang mengalami kenaikan disetiap perlakuan yaitu dari $\mathrm{pH}$ awal tanah 4,69 menjadi berkisar antara 5,64 sampai 6,98 . Untuk N-total tanah pada perlakuan tanpa vermikompos mengalami penurunan dari $0,17 \%$ menjadi berkisar $0,07 \%$, tetapi pada perlakuan pemberian vermikompos $\mathrm{N}$-total mengalami peningkatan berturut-
Tabel 3. Pengaruh pemberian dosis vermikompos terhadap tinggi tanaman pakcoy pada tanah Ultisol Taman Bogo minggu ke-4

\begin{tabular}{cc}
\hline Perlakuan & Tinggi tanaman $(\mathrm{cm})$ \\
\hline Kontrol & $13,58 \mathrm{a}$ \\
Vermi kompos $(10 \%)$ & $20,17 \mathrm{~b}$ \\
Vermi kompos $(20 \%)$ & $15,75 \mathrm{a}$ \\
Vermi kompos (30\%) & $14,58 \mathrm{a}$ \\
\hline BNT 5\% & 3,74 \\
\hline
\end{tabular}

Keterangan: Angka yang diikuti oleh huruf yang sama menunjukkan tidak berbeda nyata dengan uji BNT pada taraf nyata BNT 5\%

Tabel 4. Pengaruh pemberian dosis vermikompos terhadap jumlah daun tanaman pakcoy pada tanah Ultisol Taman Bogo minggu ke-4

\begin{tabular}{cc}
\hline Perlakuan & Jumlah daun (helai) \\
\hline Kontrol & $6,50 \mathrm{a}$ \\
Vermi kompos $(10 \%)$ & $12,00 \mathrm{~b}$ \\
Vermi kompos $(20 \%)$ & $12,33 \mathrm{~b}$ \\
Vermi kompos $(30 \%)$ & $10,33 \mathrm{~b}$ \\
\hline BNT 5\% & 2,58 \\
\hline
\end{tabular}

Keterangan: Angka yang diikuti oleh huruf yang sama menunjukkan tidak berbeda nyata dengan uji BNT pada taraf nyata BNT 5\%

turut menjadi 0,27\%, 0,37\%, 0,63\%. Demikian juga dengan $\mathrm{C}$-organik, menurun pada tanpa perlakuan vermikompos dari, $0,66 \%$ menjadi $0,60 \%$, tetapi pada perlakuan vermikompos, meningkat secara berturutturut menjadi 1,63\%, 2,65\%, 3,50\% (Tabel 5, Tabel 6).

Tabel 5. Hasil analisis awal tanah Ultisol Taman Bogo

\begin{tabular}{clc}
\hline Sifat Kimia & \multicolumn{1}{c}{ Metode } & Nilai \\
\hline Ph & Elektrometrik & 4,69 \\
C-organik & Walkey and Black $(\%)$ & 0,66 \\
N-Total & Kjeldahl $(\%)$ & 0,17 \\
\hline
\end{tabular}

Tabel 6. Hasil analisis sifat kimia tanah setelah panen

\begin{tabular}{cccc}
\hline Perlakuan & $\mathrm{pH}$ & N-total $(\%)$ & C-Organik $(\%)$ \\
\hline Kontrol & 5,64 & 0,07 & 0,6 \\
Vermikompos $(10 \%)$ & 6,48 & 0,27 & 1,63 \\
Vermikompos $(20 \%)$ & 6,72 & 0,37 & 2,65 \\
Vermikompos $(30 \%)$ & 6,98 & 0,63 & 3,50 \\
\hline
\end{tabular}




\section{Pembahasan}

Hasil penelitian untuk tinggi tanaman pada aplikasi vermikompos $10 \%$ menghasilkan tinggi tanaman pakcoy yang terbaik dibandingkan perlakuan dosis vermikompos lainnya. Pertumbuhan tinggi tanaman pakcoy pada tanah yang dipupuk vermikompos semakin meningkat dari 7 hari setelah tanam (HST) hingga panen, hal ini sama dinyatakan oleh (Atiyeh dkk., 2000) bahwa vermikompos yang diaplikasikan ketanah media tumbuh tanaman di rumah kaca dapat meningkatkan pertumbuhan dan hasil tanaman. Hasil pengamatan tinggi tanaman pakcoy pada umur 7, 14, 21 dan 28 hari setelah tanam (HST), tanaman pakcoy yang diberi perlakuan pupuk vermikompos tumbuh lebih tinggi dibandingkan dengan tanaman pakcoy yang tidak diberi vermikompos. Hasil ini sejalan dengan hasil penelitian Mamta dkk. (2012) pada Solanum melongena, tanaman yang diberi vermikompos tumbuh lebih tinggi, daunnya lebih banyak dan buahnya lebih besar.

Untuk jumlah daun, hasil pengamatan menunjukkan bahwa pada umur 7, 14, 21 dan 28 hari setelah tanam, tanaman pakcoy yang diberi vermikompos menghasilkan jumlah daun yang lebih banyak dibandingkan dengan tanaman tanpa vermikompos.

Aplikasi vermikompos 20\% menghasilkan bobot tanaman pakcoy yang lebih tinggi dibandingkan dengan perlakuan lainnya. Untuk bobot basah perlakuan dosis vermikompos $20 \%$ menghasilkan bobot basah tanaman pakcoy yang paling baik dibandingkan tanpa vermikompos dan perlakuan vermikompos lainnya dan untuk bobot kering tanaman pakcoy, perlakuan dosis vermikompos sebesar $20 \%$ dan $30 \%$ menghasilkan bobot kering yang lebih tinggi dibandingkan dengan dosis laiinya. Peningkatan bobot kering tanaman pakcoy sejalan dengan peningkatan bobot basah tanaman pakcoy. Hal ini berarti pembentukan jaringan sel sel tanaman terus meningkat. Hasil penelitian ini sejalan dengan hasil penelitian Pant dkk. (2011) tentang aplikasi vermikompos yang dapat memperbaiki sifat biologis tanah, memperbaiki pertumbuhan tanaman, hasil dan kualitas hasil tanaman pakcoy.

$\mathrm{pH}$ tanah memberikan pengaruh baik terhadap bobot basah, bobot kering, dan jumlah daun. Untuk tinggi tanaman, $\mathrm{pH}$ tanah tidak memberikan pengaruh yang nyata. Demikian juga untuk C-organik memberikan pengaruh yang positif terhadap bobot basah, bobot kering, jumlah daun, sedangkan untuk tinggi tanaman tidak berpengaruh nyata. Sedangkan N-total memberikan pengaruh positif terhadap bobot basah dan bobot kering, untuk jumlah daun dan tinggi tanaman tidak berpengaruh.

\section{KESIMPULAN DAN SARAN}

Hasil dari penelitian dapat disimpulkan: (1) Aplikasi vermikompos meningkatkan pertumbuhan dan produksi tanaman pakcoy serta maningkatkan $\mathrm{pH}$ tanah dan kandungan hara tanah. (2) Aplikasi vermikompos pada media tanam pakcoy dengan dosis minimal $20 \%$ per bobot tanah menghasilkan bobot basah dan bobot kering terbaik dibandingkan dengan yang lainnya, sedangkan tinggi tanaman dan jumlah daun terbaik diperoleh pada aplikasi vermikompos sebesar $10 \%$ per bobot tanah.

Disarankan pada penelitian lanjutan guna mengetahui residu yang ditinggalkan oleh pupuk vermikompos. Selain itu, perlu dilakukan penelitian yang dilakukan di lahan terbuka untuk mengetahui perbedaan pertumbuhan dan hasil produksi tanaman pakcoy.

\section{DAFTAR PUSTAKA}

Atiyeh,R.M., S. Subler, C.A. Edwards, G. Bachman, J.D. Metzger, and W. Shuster. 2000. Effects of vermicomposts and composts on plant growth in horticultural container media and soil. Pedobiologia, 44: 579-590.

Mashur, G. Djajakirana, Muladno. 2001. Kajian Pebaikan Teknologi Budidaya Cacing Tanah Eisenia fetida Dengan memanfaatkan Limbah Organik Sebagai Media. Med. Pet. 24 (1): 22-34.

Mashur. 2001. Vermikompos (Kompos Cacing Tanah). Instalasi Penelitian dan Pengkajian Teknologi Pertanian (IPPTP) Mataram. Mataram. http:/ kascing.comarticlemashurvermikompos.htm. Diakses tanggal 9 Januari 2013.

Sutedjo, M.M., A.G. Kartosaputro, dan R.D.S. Sastroatmodjo. 1991. Mikrobiologi Tanah. (skripsi) Jakarta: Penerbit Rineka Cipta.

Syekhfani. 2003. Pengelolaan tanah secara organik. Dalam Agustina, L., Syekhfani, D.A. Sunarto, U. Setyobudi, H. Tarno, dan M. Muhtar (ed.). Memasyarakatkan Pertanian Organik sebagai JembatanMenuju Pembangunan Pertanian Berkelanjutan. Prosiding Lokakarya Nasional Pertanian Organik. Universitas Brawijaya Malang, $130 \mathrm{hlm}$.

Zahid, A. 1994. Manfaat Ekonomis Dan Ekologi Daur Ulang Limbah Kotoran Ternak Sapi Menjadi Kascing. Studi Kasus Di PT. Pola Nusa Duta,Ciamis. (Skripsi). Fakultas Kedokteran Hewan, Institut Pertanian Bogor, pp. 6-14. 